\title{
TRANSFER OF HEAT AND SPEED OF PLASMA PARTICLES TO POWDER PARTICLES IN THE PLASMA SPRAY PROCESS AT ATMOSPHERIC PRESSURE
}

\author{
Mihailo R. Mrdak \\ Research and Development Center IMTEL Communications a.d., \\ Belgrade, Republic of Serbia, \\ e-mail:miki@insimtel.com, \\ ORCID iD: (i)http://orcid.org/0000-0003-3983-1605
}

http://dx.doi.org/10.5937/vojtehg66-12942

FIELD: Chemical Technology

ARTICLE TYPE: Profesional Paper

ARTICLE LANGUAGE: English

\section{Summary:}

For successful powder deposition and a good quality of deposited layers, the following factors are of great importance: uniform powder injection into the plasma jet, transfer of heat and velocity of plasma particles (ions and electrons) to powder particles as well as the temperature and speed of molten powder particles before the collision with the substrate. For each powder type, depending on the distribution of particle granulation $(\mu \mathrm{m})$ and density $\left(\mathrm{kg} / \mathrm{m}^{3}\right)$, it is necessary to determine the amount of powder supply ( $\mathrm{g} / \mathrm{min})$ in the plasma for defined gas flows (I/min), types of plasma gases ( $\mathrm{Ar}, \mathrm{He}, \mathrm{H}_{2}, \mathrm{~N}_{2}$ or their mixtures) and power supply levels (kW). For the transfer of heat and speed of plasma particles to powder particles, there must be an interaction between the ions and electrons from the plasma and the powder particles. For already known plasma jet speed and temperature values at atmospheric pressure, trajectories of individual particles can be calculated using the equations of motion taking into account viscous friction and inertia. The paper describes the relation between the speed of $\mathrm{Al}_{2} \mathrm{O}_{3}$ powder injection and the velocity of individual $\mathrm{Al}_{2} \mathrm{O}_{3}$ powder particles in the plasma depending on the distance from the anode opening, as well as the relation between powder granulation and the temperature of the surface of powder particles depending on powder injection and the level of plasma gun power supply at atmospheric pressure.

Keywords: heating, particles, plasma, powder, temperatures, transfer, velocity. 


\section{Introduction}

APS - atmospheric plasma spray process is a thermal process of powder deposition which consists of injecting powder particles into the plasma jet whose particles (ions and electrons) have high speed and high temperature values and in which powder particles, molten and plasma sprayed, are deposited on the substrate surface. The plasma spray process can be described as a process of energy transfer to plasma powder particles and the transfer of energy from molten particles onto the substrate on which they are deposited. Therefore, it is very important to uniformly inject powder particles into the plasma and to achieve a good interaction between plasma particles and powder particles as well as an optimal speed and temperature of molten powder particles. Metal surface coating is an important process for many industrial purposes (Mrdak, 2016), (Mrdak, 2017, pp.30-44). The success of depositing plasma spray layers depends on skillful injection of powder particles into the plasma jet so that particles, melted without evaporating and at optimum speed, are properly deformed at the impact with the substrate so that they do not affect the substrate mechanical properties. The temperature of particles in the plasma can be controlled by varying the particle size and their physical - chemical properties, powder flow, the nature of the plasma gas and the gas flow. The process parameters should ensure the production of reproductive quality coatings on metal products for the same purpose. The parameters are based on experimental experience, and relate to: plasma arc current, composition and flow of gases and powder and a distance between a plasma gun from the substrate surface to which a coating is deposited. The general studies of the behavior of powder particles in a plasma jet during a collision with a substrate served as a basis for developing optical sensors used to determine the trajectory of particles in the plasma, as well as to measure speed and temperature of molten particles in the plasma (Vardelle et al, 1996, pp.1093-1099). Experimental studies with such sensors have demonstrated the importance of the injector (powder injector) geometry and a carrier gas flow on powder particle trajectories. For a particular morphology of particles and for a distribution of particle size granulation, particle trajectories in a plasma jet are determined by temperature and speed of particles at the time of collision with a substrate surface, and, consequently, the coating thermomechanical properties (Bianchi et al, 1997, pp.35-47).

With regard to the interaction between plasma jet particles and powder particles, this paper describes: a powder feeder with a vertical 
and controlled flow of powder and carrier gas, heat transfer from plasma particles onto $\mathrm{Al}_{2} \mathrm{O}_{3}$ powder particles, the speed of $\mathrm{Al}_{2} \mathrm{O}_{3}$ powder particles depending on the speed of powder injection at certain distances from the substrate surface and the temperature of the surface of $\mathrm{Al}_{2} \mathrm{O}_{3}$ powder particles depending on the powder injection speed and power supply at certain distances. Based on the above, the paper clearly shows that the coating properties can be changed regarding the distribution of particle granulation, the nature of the plasma gas and power supply levels, which is very important for bioinert coatings based on $\mathrm{Al}_{2} \mathrm{O}_{3}$ ceramics. The aim of the study was to describe the velocity and temperature values of individual powder particles depending on the granulation and the level of plasma gun power supply at atmospheric pressure.

\section{Injection of powder particles into the plasma jet}

For a successful deposition of powder by the plasma spray process it is important to ensure uniform injection (feeding) of powder particles into the plasma jet. Different designs of powder feeders have been developed, depending on the powder feed method. The most commonly used powder feeders are those with vertical and controlled flow of powder and powder carrier gas. Powder speed $(W s)$ for vertical transport is calculated from equation (1) (Fauchais et al, 1985, pp.1171-1178), (Xiong et al, 2004, pp.5189-5200).

$$
W_{s}=\frac{g d_{p}^{2} \rho_{p}}{18 \eta g}
$$

Where $g$ is the acceleration of gravity, $d_{p}$ - the diameter of individual particles, $\quad \rho_{p}$ - the specific mass of particles for each diameter and $\eta$ the dynamic viscosity of the carrier gas. Powder speed always defines a non-dimensional Froude number for powder and carrier gas. The Froude number for powder is calculated from equation (2) (Fauchais et al, 1985, pp.1171-1178)

$$
F_{r o}=\frac{W_{s}}{\sqrt{g d_{p}}}
$$

and for a carrier gas from equation (3),

$$
F_{r o}=\frac{V_{g}}{\sqrt{g d_{z}}}
$$


where $W_{s}$ is the powder speed, $V_{g}$ - the mean value of the carrier gas speed through a tube of a diameter $d_{s}$. The mean value of the carrier gas speed is calculated from equation (4),

$$
V_{g}=\frac{4 D_{g}}{\pi d_{s}^{2}}
$$

where $D_{g}$ is the share of the carrier gas flow. The minimum carrier gas flow and the capacity are calculated for each tube from the relation between the $D_{p}$ powder flow and the $D_{g}$ carrier gas flow, given by equation (5) (Xiong et al, 2004, pp.5189-5200).

$$
\mu=\frac{D_{p}}{D_{g}}=3 \cdot 10^{-5}\left(F_{\text {ro }}\right)^{4}
$$

This equation enables the calculation of the maximum flow of powder for a given carrier gas flow rate in a tube of a certain diameter (d). The optimum parameters must be determined for each powder taking into account: mean particle size, particle morphology, specific weight, chemical composition and melting temperature. Powder particles are typically injected directly into the anode or near the plasma jet exit from the anode at certain angles depending on the nozzle design and the powder characteristics. The powder should have a required kinetic energy in order to penetrate into the plasma jet. Penetration of particles is insufficient if the kinetic energy of powder particles is very small particles move towards cooler plasma zones, remaining unmelted. If the kinetic energy of particles is too high, they pass through the entire plasma jet and also move towards cooler areas. The carrier gas share must be set for the average powder diameter and density as well as for the plasma jet density in order for powder particles to penetrate into the plasma jet axis.

\section{Transfer of heat from the plasma to powder particles}

The transfer of heat from plasma particles (ions and electrons) to powder particles takes place in two successive stages: heat transfer from plasma by convection (hot plasma flow) into powder particles and by conduction (heat transfer by conduction within powder particles). Heat transfer that takes place by plasma particle radiation onto powder particles is negligible. Heat flow (q) transmitted by convection is defined by the Newton's law and is calculated from equation (6),

$$
q=\alpha S\left(T_{g}-T_{p}\right)
$$


where: $\alpha$ - the coefficient of thermal convection between the plasma jet and powder particles, $S$ - the surface of powder particles, $T_{g}$ - the gas temperature, $T_{p}$ - the temperature of powder particles. Heat transfer by convection takes place through the particle boundary layer. Heat transfer by conduction inside the particles is calculated from Fourier's equation (7) (Vardelle et al, 1983, pp.236-243),

$$
q_{t}=-\lambda_{p} \frac{d T}{d x}
$$

where: $q_{t}$ - the heat flow density, $\lambda_{p}$ - the coefficient of thermal conductivity, $T$ - the temperature, and $x$ - the distance. Determining the heat flow includes the determination of the variation of temperature and amount of heat transferred depending on time. The coefficient of heat transfer is expressed by equation (8),

$$
\alpha=\frac{C_{g} \eta}{P_{r}} \frac{N u}{d p}
$$

where: $C g$ - the specific heat of the plasma gas, $\eta$ - the viscosity of the gas, $d p-$ the particle diameter, $N_{u}$ - the Nusselt number, and $P_{r}-$ the Prandtl number (Xiong et al, 2004, pp.5189-5200), (Chen \& Pfender, 1983, pp.97-113). Heat transfer from plasma particles to the injected powder particles in the plasma depends on the type and flow of plasma gases, power supply of plasma guns, thermal conductivity and the granulation of powder particles. The mean value of thermal conductivity is calculated from equation (9) (Bouneder et al, 2009), (Hossain et al, 2009, pp.504-509).

$$
K=\frac{1}{T_{p}-T_{s}} \int_{T_{s}}^{T_{p}} K(s) d s
$$

where: $K$ - the gas thermal conductivity, $T_{p}$ - the plasma temperature, and $T_{s}$ - the surface temperature of powder particles. At atmospheric pressure, the mean value of thermal conductivity $(K)$ is significantly influenced by hydrogen or a mixture of hydrogen and argon as plasma gases as soon as a temperature above $4000{ }^{\circ} \mathrm{C}$ is reached. The influence of the ambient pressure is also important for the mean value of the thermal conductivity of the atmosphere. In the vacuum, at a low pressure of $6.7 \mathrm{kPa}$, the mean value $(\mathrm{K})$ is lower by $30 \%$ as a result of pressure changes. At atmospheric pressure, heat transfer is significantly reduced for the powder particles below a granulation of $15 \mu \mathrm{m}$. The same effect is achieved in a vacuum for the particles of $40 \mu \mathrm{m}$ to $50 \mu \mathrm{m}$ at a 
pressure of $6.7 \mathrm{kPa}$. Difficult melting of powder particles at low pressure is a result of lower plasma temperature, lower heat transfer coefficient and the Knudsen effect (Chen \& Pfender, 1983, pp.97-113).

\section{Speed of powder particles in the plasma at atmospheric pressure}

When the distribution of velocity and temperature of the plasma jet at atmospheric pressure is known, the trajectories of individual particles can be calculated using the equations of motion taking into account viscous friction and inertia. A particular attention should be paid to the Knudsen effect that can significantly reduce the speed of particles. The Knudsen number $(K n)$ is determined from equation $(10)$ in which $(L)$ is the main free path of a particle, and $(d)$ is the diameter of an unmelted particle (Chen, Pfender, 1983, pp.97-113).

$$
K n=\frac{L}{d}
$$

At atmospheric pressure, the Knudsen number $K n$ is $<0.01$ for particles smaller than $15 \mu \mathrm{m}$. The same effect is achieved for particles of about 50 - $60 \mu \mathrm{m}$ at a low pressure of $6.6 \mathrm{kPa}$. These experimental results were obtained in a plasma jet with a speed of 2-3 $\mathrm{M}$ at the nozzle outlet. In order for a jet plasma to carry powder particles, there must occur friction between plasma particles and powder particles. For example, powder particles of tungsten with high specific weight and the size of $50 \mu \mathrm{m}$ at a distance of $60 \mathrm{~mm}$ from the anode opening can hardly reach a speed of $180 \mathrm{~m} / \mathrm{s}$, while particles of $18 \mu \mathrm{m}$ reach a maximum speed of $220 \mathrm{~m} / \mathrm{s}$. Most of particles have the least values of velocity and acceleration. It is important to note that the particles with high speed must reach enough high temperature to achieve a good bond with the substrate.

Figure 1 shows the mean values of the speed of $\mathrm{Al}_{2} \mathrm{O}_{3}$ powder particles of $18 \mu \mathrm{m}$ in the $\mathrm{H}_{2} / \mathrm{N}_{2}(\mathrm{P}=29 \mathrm{~kW})$ plasma jet depending on the speed of powder injection and the substrate distance (Vardelle et al, 2001, pp.267-284). Powder particles in the plasma have different speed values depending on the speed of injection and the injector's distance from the substrate. The speed of powder particles at distances of $5 \mathrm{~cm}$, $10 \mathrm{~cm}$ and $16 \mathrm{~cm}$ from the anode opening shows that the injection speed and the distance between the anode and the substrate greatly affect the speed of particles in the plasma. In the plasma jet, the maximum speed is reached by $\mathrm{Al}_{2} \mathrm{O}_{3}$ particles injected at a rate of $22 \mathrm{~m} / \mathrm{s}$, which is the optimum injection rate for the granulation of $18 \mu \mathrm{m}$. At a distance of 5 
$\mathrm{cm}$, powder particles injected at a speed of $22 \mathrm{~m} / \mathrm{s}$ reach a maximum speed of $300 \mathrm{~m} / \mathrm{s}$.

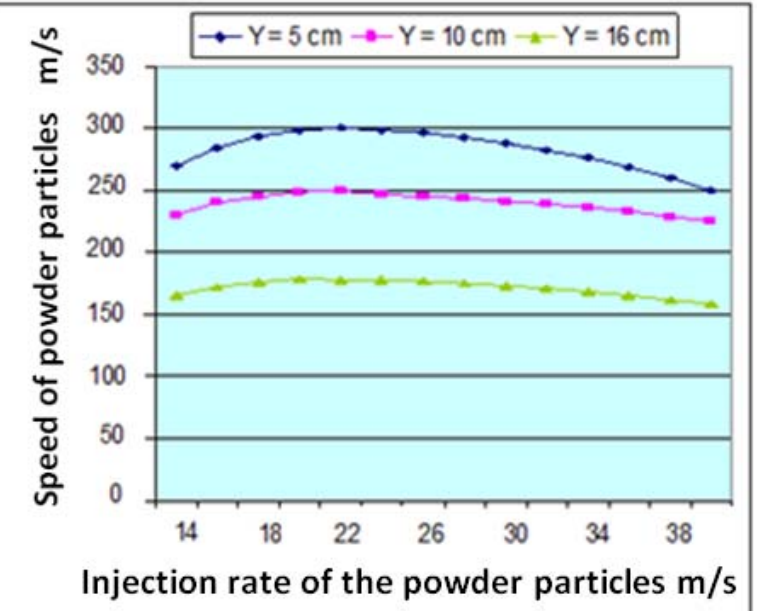

Figure 1 - Speeds particles in the plasma depending on the speed of injection and the substrate distance

Puc. 1 - Скорость частиц в плазме, в зависимости от скорости струи и расстояния между струей и покрытием

Слика 1 - Брзине честица у плазми зависно од брзине ињектирања и одстојања подлоге

The speed of powder particles decreases with the distance. At a distance of $10 \mathrm{~cm}$, particles injected with an optimum speed of $22 \mathrm{~m} / \mathrm{s}$ reach a maximum speed of $250 \mathrm{~m} / \mathrm{s}$, while at a distance of $16 \mathrm{~cm}$ they reach a speed of $170 \mathrm{~m} / \mathrm{s}$. The optimal speeds of injection of powder particles are directly related to the size of granulation. Optimum injection speed values for $\mathrm{Al}_{2} \mathrm{O}_{3}$ particles of other dimensions are shown in Table 1 (Vardelle et al, 2001, pp.267-284).

Table 1 - Optimal injection speeds for $\mathrm{Al}_{2} \mathrm{O}_{3}$ particles of individual granulations Таблица 1 - Оптимальная скорость нанесения частиц $\mathrm{Al}_{2} \mathrm{O}_{3}$ отдельных гранулятов Табела 1 - Оптималне брзине ињектирања честица $\mathrm{Al}_{2} \mathrm{O}_{3}$ за поједине гранулате

\begin{tabular}{|l|l|}
\hline $\begin{array}{l}\text { Particle } \\
\text { dimensions } \mu \mathrm{m}\end{array}$ & $\begin{array}{l}\text { Speed } \\
\text { Injection } \mathrm{m} / \mathrm{s}\end{array}$ \\
\hline 18 & 22 \\
23 & 20 \\
39 & 12 \\
46 & 9 \\
\hline
\end{tabular}




\section{Surface temperature of powder particles}

The quality of deposited layers is significantly influenced not only by the speed of powder particles but also by the temperature of the surface of molten powder particles, which depends on the amount of heat transferred from the plasma particles (ions and electrons) to powder particles. Figure 2 shows the surface temperature of $\mathrm{Al}_{2} \mathrm{O}_{3}$ powder particles with a granulation of $18 \mu \mathrm{m}$ in the $\mathrm{H}_{2} / \mathrm{N}_{2}(\mathrm{P}=29 \mathrm{~kW})$ plasma jet as a function of the injection speed and the distance from the anode opening. The surface temperature of particles in the plasma jet increases initially at a distance of $4 \mathrm{~cm}$ from the anode opening because of heat transfer from plasma particles to powder particles in order to achieve the maximum value at a distance of $8 \mathrm{~cm}$, and then decreases as the distance from the anode opening increases. For the injection speed values of $14 \mathrm{~m} / \mathrm{s}, 20 \mathrm{~m} / \mathrm{s}$ and $25 \mathrm{~m} / \mathrm{s}$, particles reach approximately the same maximum surface temperatures in the range from $2320^{\circ} \mathrm{C}$ to 2325 ${ }^{\circ} \mathrm{C}$. The differences in maximum surface temperatures are small, indicating that the speed of injection does not significantly affect the maximum surface temperature of particles of the same granulation. For achieving the maximum surface temperature in powder particles, the distance from the anode opening is more important than the injection speed (Vardelle et al, 1983, pp.236-243).

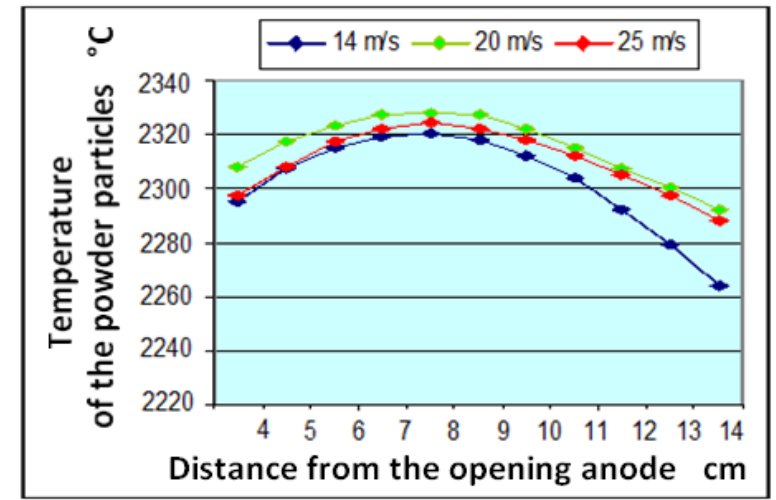

Figure 2 - Temperature of the surface of particles depending on the speed of injection and distances

Puc. 2 - Температура поверхности частиц, в зависимости от скорости струи напыления и расстояния между струей и покрытием

Слика 2 - Температуре површине честица у зависности од брзине ињектирања и одстојања 
Figure 3 shows the changes in the surface temperature of $\mathrm{Al}_{2} \mathrm{O}_{3}$ powder particles of $18 \mu \mathrm{m}$ injected with an optimum speed into $\mathrm{Ar} / \mathrm{H}_{2}$ plasma with a power of $21 \mathrm{~kW}$ and $29 \mathrm{~kW}$.

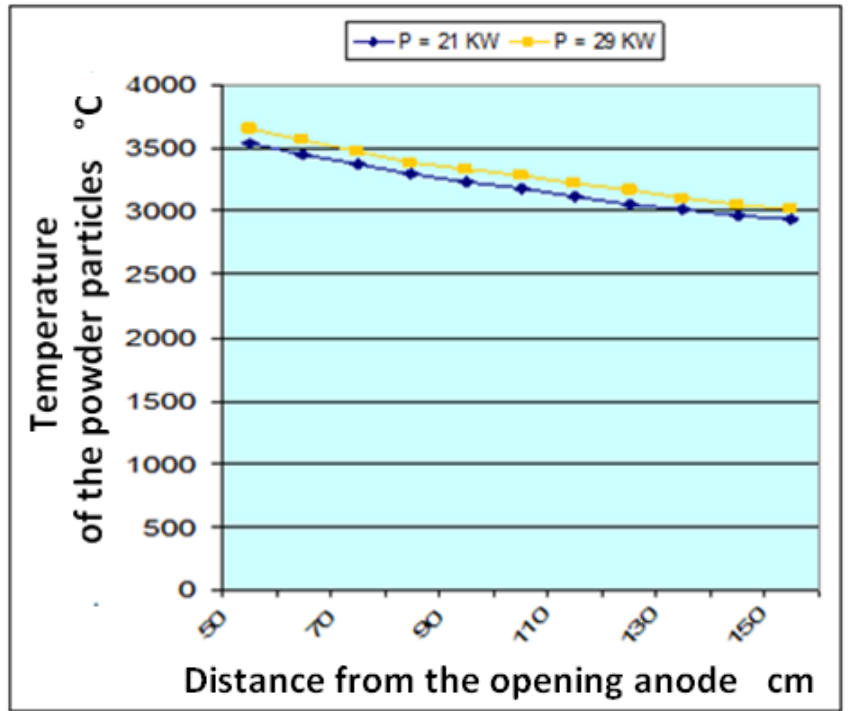

Figure 3 - Surface temperature of $\mathrm{Al}_{2} \mathrm{O}_{3}$ particles in plasma with a power of 21 and 29 $k W$

Puc. 3 - Температура поверхности частиц $\mathrm{Al}_{2} \mathrm{O}_{3}$ в плазме, мощностью 21 и 29 $\kappa B m$

Слика 3 - Температуре површине честица $\mathrm{Al}_{2} \mathrm{O}_{3}$ у плазми, снаге 21 и $29 \mathrm{~kW}$

The surface temperature of powder particles is directly related to the plasma gun power supply and the distance from the anode opening. Due to a high energy of the plasma jet, the surface temperature of powder particles is much higher than the melting temperature, which always causes a part of powder to evaporate. The highest temperature on the surface is found in powder at a distance of $50 \mathrm{~mm}$ from the andode opening. For the plasma gun power supply of $29 \mathrm{~kW}$, powder particles reach a maximum surface temperature of $3650{ }^{\circ} \mathrm{C}$, and for the power supply of $21 \mathrm{~kW}$, particles reach a maximum surface temperature of 3550 ${ }^{\circ} \mathrm{C}$. The influence of the plasma gun power supply on the surface temperature of powder particles is obvious. The increase of the power supply from $21 \mathrm{~kW}$ to $29 \mathrm{~kW}$ results in increasing the particle surface temperature difference for about $100{ }^{\circ} \mathrm{C}$. At a distance of $140 \mathrm{~cm}$ from the anode opening, the particle surface temperature decreases significantly: the deposition power of $29 \mathrm{~kW}$ results in a drop in 
temperature of $600{ }^{\circ} \mathrm{C}$, while the deposition power of $21 \mathrm{~kW}$ leads to the temperature drop of $500{ }^{\circ} \mathrm{C}$. This is why it is essential to determine the site of powder injection and the distance between the substrate and the anode opening for obtaining high quality of deposited layers.

Figure 4 shows the effect of the $\mathrm{Al}_{2} \mathrm{O}_{3}$ powder particle size on the surface temperature with regard to distance.

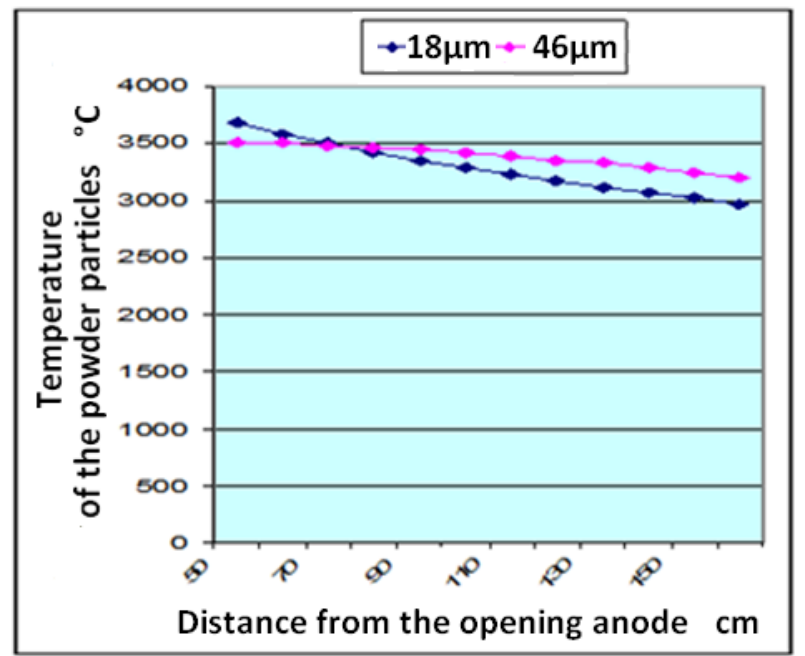

Figure 4 - The effect of the $\mathrm{Al}_{2} \mathrm{O}_{3}$ powder particle size on the surface temperature

Puc. 4 - Воздействие величины частиц $\mathrm{Al}_{2} \mathrm{O}_{3}$ порошка на температуру поверхности

Слика 4 - Утицај величине честица праха $\mathrm{Al}_{2} \mathrm{O}_{3}$ на температуру површине

Particles with a size of $18 \mu \mathrm{m}$ reach a higher temperature than particles of $46 \mu \mathrm{m}$, but they also cool down faster (Fauchais, 2004, p.R86-R108). The particles reach a maximum surface temperature at a distance of $50 \mathrm{~mm}$ from the anode opening, and reach the lowest value at a distance of $160 \mathrm{~mm}$. The maximum surface temperature of $3670{ }^{\circ} \mathrm{C}$ can be achieved at a particle size of $18 \mu \mathrm{m}$ and the maximum surface temperature of $3510{ }^{\circ} \mathrm{C}$ is achieved at a particle size of $46 \mu \mathrm{m}$. With the increase in the distance of $70 \mathrm{~cm}$ from the anode opening, the temperature of the particle surface decreases to the same value of 3490 ${ }^{\circ} \mathrm{C}$, regardless of a large difference in the particle size. Further increase of the distance from the anode opening significantly increases the difference in surface temperature and, at a distance of $160 \mathrm{~mm}$, the temperature is $300{ }^{\circ} \mathrm{C}$ (Fauchais, 2004 p.R86-R108) for $\mathrm{Al}_{2} \mathrm{O}_{3}$ powder of $18 \mu \mathrm{m}$. 
Figure 5 shows the influence of the plasma gun power supply on the surface temperature of $\mathrm{Al}_{2} \mathrm{O}_{3}$ particles of $18 \mu \mathrm{m}$.

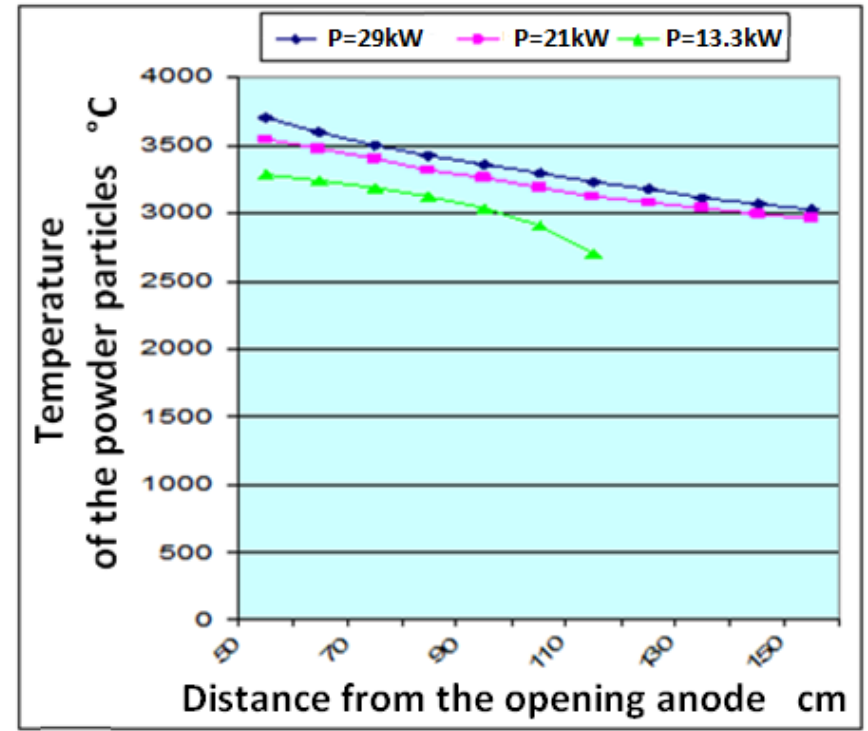

Figure 5 - Effect of the plasma gun power supply on the surface temperature of $\mathrm{Al}_{2} \mathrm{O}_{3}$ particles

Puc. 5 - Воздействие мощности плазменного распылителя на температуру поверхности частиц $\mathrm{Al}_{2} \mathrm{O}_{3}$

Слика 5 - Утицај снаге напајања плазма-пиштоља на температуру површине честица $\mathrm{Al}_{2} \mathrm{O}_{3}$

The highest surface temperature of $3670{ }^{\circ} \mathrm{C}$ is reached by powder particles with a maximum plasma gun power of $29 \mathrm{~kW}$. With the decrease of plasma gun power supply to a level of $21 \mathrm{~kW}$, the surface temperature of powder particles also decreases for $100{ }^{\circ} \mathrm{C}$ at a distance of $50 \mathrm{~mm}$ from the anode opening. The difference in the surface temperature of powder particles for these two power supply levels is reduced to a level of $40{ }^{\circ} \mathrm{C}$ for a distance of $150 \mathrm{~mm}$ from the anode opening. In plasma without hydrogen, the plasma gun power supply is only $13.3 \mathrm{~kW}$. The surface temperature of powder particles is much lower at a distance of 50 $\mathrm{mm}$ from the anode opening $-3300{ }^{\circ} \mathrm{C}$. This value is lower by $450{ }^{\circ} \mathrm{C}$ in relation to the value of the surface temperature of particles deposited with a $\mathrm{Ar} / \mathrm{H}_{2}$ mixture of gases. The plasma jet without hydrogen is much shorter, and the speed values of powder particles and the plasma are lower as well. Due to a shorter plasma jet, the surface temperature of 
particles rapidly decreases with a distance from the anode opening and it is only $2750{ }^{\circ} \mathrm{C}$ at a distance of $110 \mathrm{~mm}$.

Figure 6 shows the values of the surface temperature of $\mathrm{Al}_{2} \mathrm{O}_{3}$ powder particles depending on the share of hydrogen as plasma gas for the same level of the plasma gun power supply.

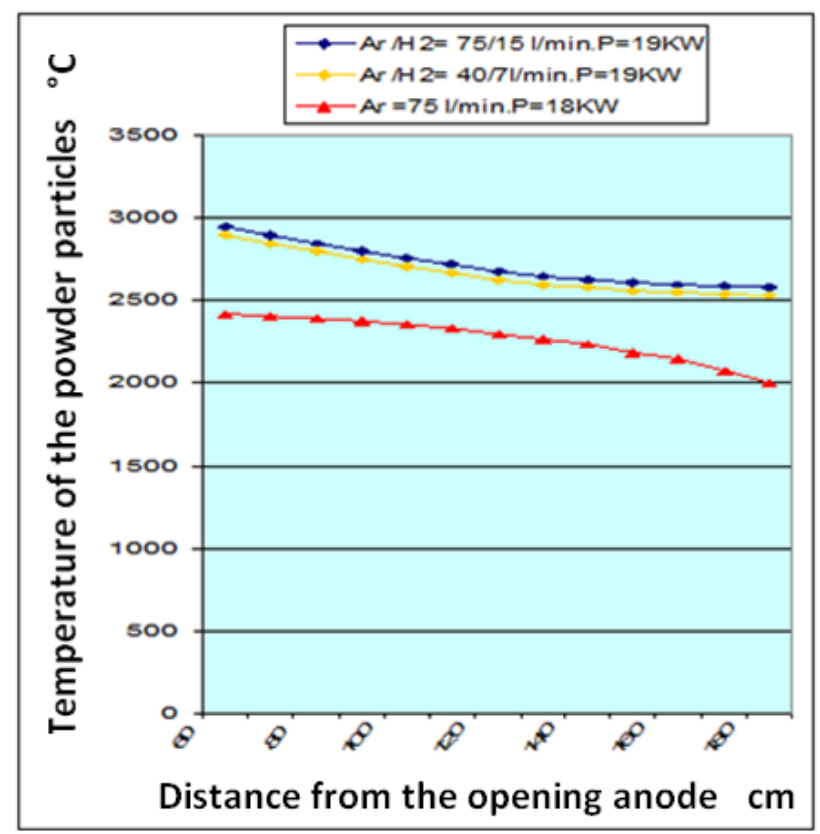

Figure 6 - Effect of $\mathrm{H} 2$ on the surface temperature of $\mathrm{Al}_{2} \mathrm{O}_{3}$ powder particles Puc. 6-Воздействие $\mathrm{H} 2$ на температуру поверхности частиц порошка $\mathrm{Al}_{2} \mathrm{O}_{3}$ Слика 6 - Утицај $\mathrm{H} 2$ на температуру површине честица праха $\mathrm{Al}_{2} \mathrm{O}_{3}$

In plasma with pure argon, the surface temperature of powder particles is lower for $500^{\circ} \mathrm{C}$. At a distance of $60 \mathrm{~mm}$, powder particles have a surface temperature of $2400{ }^{\circ} \mathrm{C}$ which drops to a level of $2000{ }^{\circ} \mathrm{C}$ at a distance of $170 \mathrm{~mm}$ from the anode opening. For the same power supply of $19 \mathrm{~kW}$, the same argon / hydrogen ratio, and two times lower share of hydrogen, powder particles have a lower surface temperature for $50{ }^{\circ} \mathrm{C}$, regardless of the distance from the anode opening.

\section{Conclusion}

This paper describes the speed of powder particles for the vertical transport of powder into the plasma jet. It also presents the transfer of 
plasma particle (ions and electrons) speed to powder particles as well as the plasma heat transfer to $\mathrm{Al}_{2} \mathrm{O}_{3}$ powder particles at atmospheric pressure.

Based on the above, the following conclusions can be given.

Powder feeders with a vertical and controlled flow of carrier gas and powder provide a steady supply of powder into the plasma jet and a successful powder deposition on substrates by the plasma spray process.

The heat transfer from plasma particles to powder particles takes place exclusively by convection (hot plasma flow) and conduction (heat conduction) within powder particles, while the heat transfer by plasma radiation to powder particles is negligible.

Injection speed and the distance from the anode to the substrate affect the particle velocity in the plasma to a large extent. For a given granulation, particles reach a maximum speed at a certain distance and then the speed decreases with the distance. Optimal injection speed values are directly related to the size of granulation.

The surface temperature of powder particles in the plasma initially rises to a maximum value at a certain distance due to heat transfer, and then decreases with the distance from the anode opening. Reaching the maximum surface temperature of powder particles is more influenced by by the plasma gun power supply and the distance from the anode opening than by the injection speed.

This document has shown that the properties of $\mathrm{Al}_{2} \mathrm{O}_{3}$ powder coatings can be changed depending on particle granulation distribution, power supply levels and plasma spray distances.

\section{References}

Bianchi, L., Léger, A.C., Vardelle, M., VFardelle, A. \& Fauchais, P., 1997. Splat formation and cooling of plasma-sprayed zirconia. Thin Solid Films, 305(1-2), pp.35-47. Available at: http://dx.doi.org/10.1016/S00406090(97)80005-3.

Bouneder, M., Ageorges, H., El Ganaoui, M., Pateyron, B. \& Fauchais, P., 2009. Direct current plasma spraying of mechanofused alumina-steel particles. University of Limoges.

Chen, X. \& Pfender, E., 1983. Effect of the Knudsen number on heat transfer to a particle immersed into a thermal plasma. Plasma Chemistry and Plasma Processing, 3(1), pp.97-113. Available at: http://dx.doi.org/10.1007/BF00566030. 
Fauchais, P., 2004. Understanding plasma spraying, invited review. Journal of Physics D: Applied Physics, 37(9), p.R86-R108. Available at: http://dx.doi.org/10.1088/0022-3727/37/9/R02.

Fauchais, P., Vardelle, M.A, Vardelle, M. \& Pateyron, B., 1985. Plasma spraying and extractive metallurgy: Comparisons between mathematical modelling and measurements and between application and development. Pure and Applied Chemistry, 57(9), pp.1171-1178. Available at: http://dx.doi.org/10.1351/pac198557091171.

Hossain, M.M, Yao, Y. \& Watanabe, T., 2009. A Numerical Study of Plasma-Particle Heat Transfer Dynamics in Induction Thermal Plasmas for Glassification. Transactions on electrical and electronic engineering, 4(4), pp.504-509. Available at: http://dx.doi.org/10.1002/tee.20436.

Mrdak, M.R., 2016. Plazma sprej procesi $i$ svojstva zaštitnih prevlaka. Belgrade: IHIS Techno experts d.o.o. (in Serbian).

Mrdak, M.R., 2017. Mechanical properties and the microstructure of the plasma-sprayed ZrO2Y2O3 / ZrO2Y2O3CoNiCrAIY / CoNiCrAIY coating. Vojnotehnički glasnik/ MilitaryTechnical Courier, 65(1), pp.30-44. Available at: http://dx.doi.org/10.5937/vojtehg65-10586.

Vardelle, M., Vardelle, A., Fauchais, P. \& Boulos, M.I., 1983. Plasmaparticle momentum and heat transfer: Modelling and measurements. AlChE Journal, 29(2), pp.236-243. Available at: http://dx.doi.org/10.1002/aic.690290210.

Vardelle, M., Vardelle, A., Li, K.I., Fauchais, P. \& Themelis, N.J., 1996. Coating generation: Vaporization of particles in plasma spraying and splat formation. Pure and Applied Chemistry, 68(5), pp.1093-1099. Available at: http://dx.doi.org/10.1351/pac199668051093.

Vardelle, M., Vardelle, A., Fauchais, P., Li, K.-I., Dussoubs, B. \& Themelis, N.J., 2001. Controlling Particle Injection in Plasma Spraying. Journal of Thermal Spray Technology, 10(2), pp.267-284. Available at: http://dx.doi.org/10.1361/105996301770349367.

Xiong, B.H., Zheng, L.L, Srisailam, S. \& Fincke, R.J., 2004. Threedimensional simulation of plasma spray: Effects of carrier gas flow and particle injection on plasma jet and entrained particle behavior. International Journal of Heat and Mass Transfer, 47(24), pp.5189-5200. Available at: http://dx.doi.org/10.1016/j.jjheatmasstransfer.2004.07.005.

ПЕРЕДАЧА ТЕПЛА И СКОРОСТИ ЧАСТИЦ ПЛАЗМЫ ЧАСТИЦАМ ПОРОШКА В ПРОЦЕССЕ ПЛАЗМЕННОГО НАПЫЛЕНИЯ ПРИ АТМОСФЕРНОМ ДАВЛЕНИИ

Михаило Р. Мрдак

Центр исследований и развития А.О. «ИМТЕЛ коммуникации»,

г. Белград, Республика Сербия

ОБЛАСТЬ: химические технологии

ВИД СТАТЬИ: профессиональная статья

ЯЗЫК СТАТЬИ: английский 
Резюме:

Для успешного и качественного нанесения порошкового покрытия, очень важны следующие действия: равномерное впрыскивание порошка в струю плазмы, передача температуры и скорости частиц плазмы (ионов и электронов) частицам порошка $u$ температура и скорость расплавленных частиц порошка до соприкосновения с основанием. По каждому виду порошка в зависимости от распределения грануляции частиц ( $\mu \mathrm{m}) \mathrm{u}$ плотности (ка/м3) необходимо определить количество порошка (г/мин) в плазме для определения потока газов (л/мин), видов плазменных газов ( $\mathrm{Ar}, \mathrm{He}, \mathrm{H} 2, \mathrm{~N} 2$ или их смеси) и уровня мощности $(\kappa B m)$. Для того чтобы осуществилась передача тепла и скорости частиц плазмы на частицы порошка должно произойти взаимодействие между ионами и электронами плазмы $u$ частицами порошка. В случае, если известны скорость и температура плазменной струи при атмосферном давлении, то можно рассчитать траекторию отдельных частиц с помощью уравнений движения, учитывая вискозное трение и инерцию. В данной работе представлены скорость напыления порошка $\mathrm{Al}_{2} \mathrm{O}_{3} \mathrm{u}$ скорость отдельных частиц порошка $\mathrm{Al}_{2} \mathrm{O}_{3}$ в плазме, 8 зависимости от расстояния от анодного отверстия, а также связи грануляции порошка и температуры поверхности частии порошка, в зависимости от впрыска порошка и уровня мошности плазменного распылителя при атмосферном давлении.

Ключевые слова: нагрев, частицы, плазма, порошок, температура, передача, скорость.

ПРЕНОС ТОПЛОТЕ И БРЗИНЕ ЧЕСТИЦА ПЛАЗМЕ НА ЧЕСТИЦЕ ПРАХА У ПЛАЗМА-СПРЕЈ ПРОЦЕСУ НА АТМОСФЕРСКОМ ПРИТИСКУ

Михаило Р. Мрдак

Истраживачки и развојни центар ИМТЕЛ комуникације а.д.,

Београд, Република Србија

ОБЛАСТ: хемијске технологије

ВРСТА ЧЛАНКА: стручни чланак

ЈЕЗИК ЧЛАНКА: енглесКИ

\section{Сажетак:}

За успешно депоновање праха и добар квалитет депонованих слојева од великог значаја је равномерно ињектирање праха у млаз плазме, пренос топлоте и брзине честица плазме (јона $и$ електрона) на честице праха, као и температура и брзина истопљених честица праха пре судара са подлогом. За сваки тип праха, у зависности од расподеле гранулације честица ( $\mu \mathrm{m})$ u 
густине $\left(\mathrm{kg} / \mathrm{m}^{3}\right)$, неопходно је одредити количину дотура праха (g/min) у плазми за дефинисане протоке гасова (I/min), типове плазма гасова ( $\mathrm{Ar}, \mathrm{He}, \mathrm{H}_{2}, \mathrm{~N}_{2}$ или њихове мешавине) и нивое снаге (kW). Да би дошло до преноса топлоте и брзине честица плазме на честице праха, мора доћи до интеракције између јона и електрона из плазме и честица праха. За познате брзине и температуре млаза плазме на атмосфрерском притиску могу се израчунати путање појединих честица применом једначине кретања, узимајући у обзир вискозно трење и инерцију. У раду је приказана веза између брзине ињектирања праха $\mathrm{Al}_{2} \mathrm{O}_{3}$ и брзине појединих честица праха $\mathrm{Al}_{2} \mathrm{O}_{3}$ у плазми у зависности од одстојања отвора аноде, као и веза гранулације праха и температуре површине честица праха у зависности од ињектирања праха и нивоа снаге напајања плазма пиштоља на атмосферском притиску.

Кључне речи: загревање, честице, плазма, прах, температуре, пренос, брзине.

Paper received on / Дата получения работы / Датум пријема чланка: 16.01.2017.

Manuscript corrections submitted on / Дата получения исправленной версии работы / Датум достављања исправки рукописа: 28.07.2017.

Paper accepted for publishing on / Дата окончательного согласования работы / Датум коначног прихватања чланка за објављивање: 30.07.2017.

(c) 2018 The Author. Published by Vojnotehnički glasnik / Military Technical Courier (www.vtg.mod.gov.rs, втг.мо.упр.срб). This article is an open access article distributed under the terms and conditions of the Creative Commons Attribution license (http://creativecommons.org/licenses/by/3.0/rs/).

() 2018 Автор. Опубликовано в «Военно-технический вестник / Vojnotehnički glasnik / Military Technical Courier» (www.vtg.mod.gov.rs, втг.мо.упр.срб). Данная статья в открытом доступе и распространяется в соответствии с лицензией «Creative Commons» (http://creativecommons.org/licenses/by/3.0/rs/).

(c) 2018 Аутор. Објавио Војнотехнички гласник / Vojnotehnički glasnik / Military Technical Courier (www.vtg.mod.gov.rs, втг.мо.упр.срб). Ово је чланак отвореног приступа и дистрибуира се у складу са Creative Commons licencom (http://creativecommons.org/licenses/by/3.0/rs/).

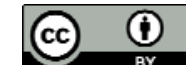

